\title{
Entry mode Strategies and Performance of Japanese MNCs in Australia and New Zealand: the Role of Japanese Employees
}

\author{
Sriya Kumarasinghe (Corresponding author) \\ Department of Accountancy \& Business Law, University of Otago \\ PO Box 56, Dunedin 9054, New Zealand \\ Tel: 64-3-479-8120 E-mail: sriya.kumarasinghe@otago.ac.nz
}

\author{
Yasuo Hoshino \\ Graduate School of Accounting, Aichi University \& University of Tsukuba \\ 2-10-31, Tsutsui, Higashi-ku, Nagoya 461-8641, Japan \\ E-mail: hoshino@aichi-u.ac.jp
}

\begin{abstract}
This study investigates different entry modes and staffing practices, and their influence on performance in Japanese subsidiaries in Australia and New Zealand. Data from 275 Japanese subsidiaries were derived from the Toyo Keizai data bank of Japanese overseas investments (Kaigai Shinshutsu Kigyou Souran) for the period from 2003 to 2008. The major assumption of this paper is that Japanese multinational corporations (MNCs) use their staffing policies as a means of exerting more influence on performance combined with other factors such as experience, industry, and the type of ownership. The study reveals that within the sample Japanese subsidiaries in Australia have a higher percentage of high performance companies than in New Zealand. The existence of Japanese employees, ownership and industry are shown as predictors of performance.
\end{abstract}

Keywords: Japanese multinational corporations, ownership, performance, staffing policies, Australia, New Zealand

JEL Classifications: G320, G340 


\section{Introduction}

With the globalization of trade activities the spread of multinational corporations (MNCs) has become very fast and complex. During the last few decades Japanese foreign direct investment (JFDI) and MNC activities have spread all over the world attracting much attention from business researchers and academic scholars. Ownership structures (Kasuga, 2008; Cieslik \& Ryan, 2009), entry mode and performance outcomes (Konopaske et.al, 2002; Anand \& Delios, 1997; Nitsch et.al, 1996; Ito \& Rose, 1994), establishment and survival (Delios \& Ensign, 2000), subsidiary size and autonomy (Beamish \& Jae, 2005; Johnston \& Menguc, 2007) and performance between wholly owned subsidiaries and joint ventures (Makino \& Kent, 2000) were the issues discussed extensively. Previous studies have focused on geographical locations such as United States (Alba et.al, 2008), Europe (Mansour \& Hoshino, 2002), Canada (Delios \& Ensign, 2000), China (Beamish \& Ruihua, 2002), Thailand (Siripaisalpipat \& Hoshino, 2000), Taiwan (Yeh \& Hoshino, 2000), and Australia (Ben_Youssef \& Hoshino, 2007).

The triangle of New Zealand, Australia and Japan is a crucial one for the following reasons. New Zealand's trading relationships are becoming increasingly based around the Pacific Rim countries. New Zealand's three largest export markets - Australia, Japan and the United States - accounted for $43 \%$ of New Zealand's exports and $40 \%$ of imports in the year ended 2007. The two-way trade amounted to $\$ 15.3$ billion with Australia taking $21 \%$ of New Zealand's exports and supplying $21 \%$ of imports (Statistics New Zealand, 2008). On the other hand, Japan has been a leading trading partner of both Australia and New Zealand for many years. Today, almost all major Japanese MNCs have a significant share in the Australian market. It is Japan's biggest foreign direct investment (FDI) destination in the Asia Pacific. The factors such as improvement of infrastructure, rapid development in Australia, government policies, trade friction between Japan and the US in 80s, the high value of the Japanese yen, high domestic labour cost, stagnation of the Japanese economy, and rapid globalization have contributed to this trend (De Silva, 2006). Such inter-connectedness creates a significant impact on these three countries' economies.

Regardless of the factors mentioned above, there exists a gap in empirical research on FDI in the Pacific region, especially in New Zealand (Scott-Kennel, 2004). Therefore, the primary objective of this paper is to provide empirical evidence on Japanese FDI performance in Australia and New Zealand. According to our knowledge this research is the first to examine the impact of ownership structure, entry mode, industry, and firm-specific characteristics on the performance of Japanese subsidiaries in New Zealand and also to conduct a comparison with the Japanese subsidiaries in Australia. This paper will attempt to investigate whether the staffing policies in Japanese subsidiaries combined with their entry mode choices and ownership strategies would be the possible indicators of their financial performance. 
This paper aims to contribute to the existing literature by providing additional information on Japanese foreign direct investment (JFDI) in Australia and New Zealand and also by analyzing Japanese subsidiaries in Australia and New Zealand as one set of data to represent the JFDI in the Pacific region. We assume that mutual inter-dependence of Australia and New Zealand in their economic efforts and the cultural closeness will allow combined research and side by side comparisons.

The flow of the paper is as follows. Section 2 briefly reviews relevant theoretical and empirical literature on JFDI. Section 3 presents the data sources, sample composition, and the model to be tested. Section 4 interprets the results and Section 5 summarizes the findings of the study with comments, limitations and future research possibilities.

\section{Literature on Entry mode strategies and firm performance}

\subsection{The choice of entry mode}

The choice of entry mode into foreign markets is one of the most important decisions made by the MNCs. After making decisions on whether to orient towards the global market, local and overseas, or local market, and whether they go for an equity-based entry mode, they take the second step of deciding on the percentage of ownership. In closed markets with high tariffs on imported goods, MNCs have no other choice than starting local production. There they form joint ventures with local partners. Japanese firms clearly intend to adopt $100 \%$ ownership if the host country permits them to do so (Okamoto, 1998). Whichever approach is to be adopted, the primary objective is to optimize performance.

In previous research on entry mode and performance of 173 Japanese FDI in 1994 in Western Europe, it was predicted that the Greenfield ${ }^{1}$, wholly-owned subsidiaries would perform best, followed by joint ventures and acquisitions. The results provided strong evidence of poor performance by acquisitions versus Greenfield and joint ventures (Nitsch et al., 1996). Research by Harzing (2002) on management of entry modes reported that Greenfield companies are more strongly controlled by the headquarters than in acquisitions and have a higher level of expatriate presence.

Research by Ogasavara and Hoshino (2007) examined entry mode strategies based on non-conventional forms of joint ventures and found that Japanese-Japanese joint ventures with a partner that has previous experience in the local market performed better than wholly-owned subsidiaries and traditional international joint ventures. According to a recent research by the same authors on Japanese subsidiaries in Brazil, the accumulation of both international and local experiential knowledge can positively affect subsidiary performance (Ogasavara and Hoshino, 2009).

Having noted the previous research findings, we hypothesize:

1 Greenfield firm is a firm enters a foreign market via FDI setting up an entirely new plant (Gorg, 2000). 
$H 1$ a. Subsidiaries which used Greenfield as the initial entry mode will perform better than mergers and acquisitions in Australia and New Zealand.

$H 1$ b. Wholly-owned subsidiaries will perform better than joint-ventures in Australia and New Zealand.

\subsection{Industry}

Previous research has confirmed that promotion of exports and securing imports were to be the primary rationale for JFDI. There are other motivations for JFDI such as labour cost and resource access. Like Canada, Sweden and Norway, Australia has been attracted by both the natural resource industries and technologically sophisticated industries. Delios and Ensign (2000) found that region and industry drew JFDI to Canada and influenced the subsidiary survival.

A recent work by Rasouli and Hoshino (2007) on 263 Japanese subsidiaries in India examined the effects of equity ownership, size, entry strategy and subsidiary age on the sales growth ratio and the subsidiary's survival. They concluded that MNCs prefer to acquire high levels of ownership in the manufacturing sector. The results of their research further indicated that: capital; age of the venture; the number of employees; and, full ownership, affect survival of the subsidiary. Mansour and Hoshino (2002) also examined the impact of firm and industrial factors on entry mode choice of the Japanese MNCs in Europe. Their research was based on 324 Japanese firms in Europe over the period of 1994 to 1998. The study found that international experience and resource-based industries had a positive influence on the choice of shared ownership structure. Additionally they found that firm size and intangible assets, measured by the R\&D and advertising, were not significantly related to entry mode. Conducting a research on Japanese subsidiaries in Australia between 1992 and 2002 Ben_Youssef and Hoshino (2007) confirmed the influence of affiliated industry on the performance in Japanese subsidiaries.

Incorporating the above literature we hypothesized the following.

H2. Industry type has a significant influence on the performance of a Japanese subsidiary in Australia and New Zealand.

\subsection{Staffing policies of Japanese subsidiaries}

The parent-subsidiary relationship is a fundamental aspect of corporate control and governance in MNCs. Empirical research on the ownership policies of the MNCs towards their subsidiaries has revealed that the parent companies intervene in the subsidiary activities not only through the ownership but also through the direct participation in the management team. Particularly for Japanese MNCs their management practices have been seen as significant contributing factors in Japan's economic success, thus many enthusiasts attempt to apply such specific approaches to other countries. In the case of Japanese subsidiaries in 


\section{Macrothink}

Australia, some Japanese management practices have been effective while others failed, but appeared as trying to keep Japanese identity through incorporating them into the management systems in their subsidiaries in the overseas (Bamber et.al, 1992).

Expatriate managers play an important role in representing and implementing the corporate objectives of a MNC. They often serve as a control mechanism to ensure achieving corporate goals and objectives (Beamish \& Inkpen, 1998). Beamish and Inkpen (1998) found the number of Japanese expatriates have been declining for some time. They assumed that the Japanese MNCs will shed their ethnocentric bias and hire the best managers they can find whether Japanese or non-Japanese.

Konopaske et al. (2002) carried out research on the role of staffing as a moderating factor between entry mode strategy and performance of Japanese MNCs in the worldwide. They hypothesized FDI performance based on the firm resources, organization structure, technology transfer, and ethnocentric and polycentric staffing. Revealing significantly different results between the wholly owned subsidiaries and the joint ventures, they reported that ethnocentric staffing was negatively related to the performance in joint ventures, but in the case of wholly owned subsidiaries, ethnocentric staffing was positively and significantly related.

Assuming Japanese parent companies wish to ensure that Japanese management systems are adopted in their subsidiaries by sending Japanese expatriates to the host countries, we hypothesize,

H3 a. Subsidiaries with Japanese employees in the staff will perform better than subsidiaries without Japanese employees in Australia and New Zealand.

H3 b. Subsidiaries with Japanese Chief Executive Officer (CEO) will perform better than subsidiaries without a Japanese CEO in Australia and New Zealand.

\section{Methodology}

\subsection{Scope of the study}

The main objective of this study is to examine the influence of different entry mode strategies, ownership structures, industry, and staffing policies on the subsidiary performance in Australia and New Zealand. It also intends to explore the differences of JFDI between the two countries.

\subsection{Sample}

The sample consists of 31 (6.4\% of the population) Japanese subsidiaries in New Zealand and 244 (9.7\% of the population) Japanese subsidiaries in Australia. The data was extracted from the Toyo Keizai data bank of Japanese overseas Investments (Kaigai Shinshutsu Kigyou 
Souran $(K S K S)$ ) published between 2003 and 2008. KSKS has been publishes annually since 1970 and has been used widely (Cieslik \& Ryan, 2009; Kasuga, 2008; Ogasavara \& Hoshino, 2007; Ben_Youssef \& Hoshino, 2007; Rasouli \& Hoshino 2007; Konopaske et.al, 2002; Delios \& Ensign, 2000). It provides a list of overseas investment activities of Japanese corporations. The total number of observations for New Zealand was 485 and for Australia, the number was 2,504. The sample was selected based on the availability of performance data. There were only a small number of subsidiaries with performance data and we included them all. Subsidiaries with at least two years experience have been used by previous researchers such as Woodcock et.al. (1994), Nitsch et.al. (1996), and Ben_Youssef \& Hoshino (2007). We also followed the same rule.

The 31 subsidiaries in the New Zealand sample included 12 firms involved in wholesale and retail trading, 8 in the travel and hotel industry, 7 in the agriculture sector, and 4 in the real estate and finance sector. Among the Australian sample, there were 79 in wholesale and retail business, 42 in agriculture, 37 in manufacturing, 36 in real estate and finance, 25 in travel, 8 in mining, 6 in transport and logistics, and 11 others in miscellaneous businesses including education and consultation services.

\subsection{Measures}

The dependent variable, independent variables and control variable were all derived from the KSKS database and are discussed below.

\subsubsection{Dependent variable}

The primary objective of our research was to find out whether there were any significant influences of ownership structure, entry mode strategies, industry and the staffing policies on the performance. Secondly, to investigate whether there were any differences in those attributes among the Japanese subsidiaries in New Zealand and Australia. Therefore the dependent variable was performance. Financial performance data was not available to the public but there was only one subjective measure of performance available in the KSKS database. The senior managers of the subsidiaries assessed the performance of their company in terms of loss, break-even, or gain for the given financial year. This was the only performance indicator the firms disclosed to the databank and it has been used as a proxy for performance in previous research on Japanese subsidiaries (Cieslik \& Ryan, 2009; Kasuga, 2008; Ogasavara \& Hoshino, 2007). Although the measure is subjective by nature, it indicates the performance in a relatively comparable manner. Therefore we believe it is appropriate for our requirement. The Japanese subsidiaries in the sample have been engaged in business activities the respective countries for about 20 years on average. Considering the economic objectives of an organization we assumed that the investors expect a profit over their investment straight from the year of establishment or at least after a few years of establishment leaving some time to recover the initial costs. Not a single firm would expect to break-even after 20 years of experience. Therefore we assumed that the break-even would be 
closer to loss than gain. Based on that argument we created a dichotomous variable for performance in which a gain was considered as high performance $=1$ and break-even and loss were considered as low performance $=0$ (Ogasavara and Hoshino, 2007).

\subsubsection{Independent variables}

Based on our hypotheses, initial entry mode, ownership, industry, and staffing policy were considered as independent variables. Ownership, industry and staffing policy have more than one variable.

Table 1. Description of the sample by ownership structure

\begin{tabular}{|l|c|c|c|c|c|c|}
\hline Description & $\begin{array}{c}\text { New } \\
\text { Zealand }\end{array}$ & $\begin{array}{c}\text { \% of } \\
\text { NZ total }\end{array}$ & Australia & $\begin{array}{c}\% \text { of } \\
\text { Aus total }\end{array}$ & Total & $\begin{array}{c}\text { \% of } \\
\text { total }\end{array}$ \\
\hline Ownership 1 & & & & & & \\
Wholly-owned & 23 & 74.2 & 181 & 74.2 & 204 & 74.2 \\
Joint ventures & 8 & 25.8 & 63 & 25.8 & 71 & 25.8 \\
Total & 31 & 100 & 244 & 100 & 275 & 100 \\
Ownership 2 & & & & & & \\
WOS (J) & 12 & 38.7 & 153 & 62.7 & 165 & 60 \\
WOS (DJ) & 11 & 35.5 & 28 & 11.5 & 39 & 14.2 \\
JV (JJ) & 4 & 12.9 & 22 & 9 & 26 & 9.5 \\
JV (JDJ) & - & & 13 & 5.3 & 13 & 4.7 \\
JV (JJL) & 1 & 3.2 & 6 & 2.5 & 7 & 2.5 \\
JV (DJL) & 3 & 9.7 & 8 & 3.3 & 11 & 4 \\
JV (JDJL) & - & - & 2 & 0.8 & 2 & 0.7 \\
JV (JL) & - & - & 12 & 4.9 & 12 & 4.4 \\
Total & 31 & 100 & 244 & 100 & 275 & 100 \\
\hline
\end{tabular}

a $\operatorname{WOS}(\mathrm{J})$ = Japanese wholly-owned, WOS $(\mathrm{DJ})=$ domestic Japanese wholly-owned, JV (JJ) = Japanese-Japanese joint ventures, JV $($ JDJ) = Japanese and domestic Japanese joint ventures, JV (JJL) = Multiple Japanese companies and local joint ventures, JV $(\mathrm{DJL})=$ domestic Japanese and local joint ventures, JV (JDJL) = Japanese, domestic Japanese, and local joint ventures, $\quad \mathrm{JV}(\mathrm{JL})=$ Japanese and local joint ventures

In the sample of New Zealand, 23 subsidiaries were wholly-owned and 8 subsidiaries were joint ventures. From the 23 wholly-owned subsidiaries, 12 were owned by Japanese companies registered in Japan and 11 were owned by Japanese companies registered in Australia. Among the joint ventures, 4 joint-venture subsidiaries were Japanese-Japanese, and 1 was a joint venture in which the investors were several companies in Japan and one company in Australia. Three other joint-ventures were funded by Japanese and Australian firms registered in Australia. In the Australian sample, 182 subsidiaries were wholly-owned by companies registered in Japan and 62 were joint ventures. We found 20 domestic Japanese wholly-owned, 23 Japanese-Japanese joint ventures, 12 Japanese and domestic Japanese joint ventures, 7 traditional (Japanese and local) joint ventures, 6 domestic 


\section{Macrothink}

Japanese and local joint ventures, and 2 Japanese, domestic Japanese, and local joint ventures (see Table 1).

For ownership 1, we identified the subsidiary as wholly-owned or joint venture. For ownership 2, subsidiaries with more than $95 \%$ of Japanese ownership were labeled as wholly-owned, and the others were considered as joint ventures. For ownership 2, we further distinguished the composition of ownership based on the information on the affiliated firms. Some parent companies of the wholly-owned subsidiaries were established in Japan, and some were registered in the host country. Similarly, we found six combinations of joint ventures among those subsidiaries. They were labeled as Japanese-Japanese; Japanese and domestic Japanese; Japanese, Japanese and a local; domestic Japanese and a local; Japanese, domestic Japanese, and a local; and Japanese and a local; the traditional type of joint venture.

Table 2. Description of the sample by industry

\begin{tabular}{|l|c|c|c|c|c|c|}
\hline Description & $\begin{array}{c}\text { New } \\
\text { Zealand }\end{array}$ & $\begin{array}{c}\% \text { of } \\
\text { NZ total }\end{array}$ & Australia & $\begin{array}{c}\% \text { of } \\
\text { Aus total }\end{array}$ & Total & $\begin{array}{c}\% \text { of } \\
\text { total }\end{array}$ \\
\hline Industry 1 & & & & & & \\
Manufacturing* & 6 & 19.4 & 72 & 29.5 & 78 & 28.4 \\
Service & 25 & 80.6 & 172 & 70.5 & 197 & 71.6 \\
Total & 31 & 100 & 244 & 100 & 275 & 100 \\
Industry 2 & & & & & & \\
Agriculture & 7 & 22.6 & 42 & 17.2 & 49 & 17.7 \\
Mining & - & - & 8 & 3.3 & 8 & 2.8 \\
Travel & 8 & 25.8 & 25 & 10.2 & 33 & 12 \\
Manufacturing** & - & - & 37 & 15.2 & 37 & 13.4 \\
Retail/wholesale & 12 & 38.7 & 79 & 32.4 & 91 & 33.1 \\
Real est/finance & 4 & 12.9 & 36 & 14.8 & 40 & 14.4 \\
Transport/logistic & - & - & 6 & 2.5 & 6 & 2.2 \\
Other & - & - & 11 & 4.5 & 11 & 4.4 \\
Total & 31 & 100 & 244 & 100 & 275 & 100 \\
\hline
\end{tabular}

* In this category we identified manufacturing subsidiaries which involved in making or processing goods by means of industrial machines

** For industry 2 we identified manufacturing subsidiaries which involved in large scale industrial operations only. Subsidiaries involved in timber, paper and food processing were added into the agriculture sector 


\section{Macrothink}

Industry also first categorized as manufacturing and service and labeled as industry 1. For industry 2, each subsidiary was identified with its industry sector. Subsidiaries involved in timber, paper, or food processing were included as agriculture related businesses. Only the large scale industrial operations were considered as industrial firms (see table 2). For staffing, there were three variables. They were, number of Japanese employees in the firm, existence of Japanese employees in the company work force, and existence of Japanese chief executive officer (CEO).

\subsubsection{Control variable}

Subsidiary performance can be affected by various factors at various levels. Number of years in operation since establishment was used as a proxy for age and it has been identified as a highly influencing factor of subsidiary performance (Konopaske et al, 2002; Johnston \& Menguc, 2007). Therefore we included company age as a control variable for this study. In order to minimize the effect of relatively skewed data, we introduced age in its log transformation.

\subsubsection{Statistical methods}

SPSS statistics package 17.0 was used to run the correlation analysis, cross-tabulation, t-test and logistic regression to test the hypothesized models.

\section{Discussion}

Based on some previous research, the purpose of our research was to investigate to what extent initial entry mode, ownership, industry and the staffing policies would be the predictors of the performance of Japanese subsidiaries in Australia and New Zealand. We applied several logistic regression models. 


\section{Macrothink}

Table 3: Means, standard deviations and correlations among all the variables $(\mathrm{N}=275)$

\begin{tabular}{|c|c|c|c|c|c|c|c|c|c|}
\hline Variables & $\begin{array}{l}\text { Initial } \\
\text { entry }\end{array}$ & age $(\ln )$ & \begin{tabular}{|c|} 
Japanese \\
emp
\end{tabular} & $\begin{array}{c}\text { Japanese } \\
\text { emp } \\
\text { exist } \\
\end{array}$ & Perform & Indus 1 & Indus 2 & $\begin{array}{l}\text { Owner } \\
\text { ship } 1\end{array}$ & $\begin{array}{l}\text { Owner } \\
\text { ship } 2 \\
\end{array}$ \\
\hline Initial entry & 1.000 & & & & & & & & \\
\hline Company age $(\ln )$ & $-.224^{* *}$ & 1.000 & & & & & & & \\
\hline Japanese emp & -.028 & -.002 & 1.000 & & & & & & \\
\hline Japanese empexist & .089 & .055 & $.580^{* *}$ & 1.000 & & & & & \\
\hline Performance & -.110 & $.208^{* *}$ & .065 & .110 & 1.000 & & & & \\
\hline Industry 1 & .002 & $.203^{* *}$ & $-.197^{* *}$ & $-.132^{*}$ & $.195^{* *}$ & 1.000 & & & \\
\hline Industry 2 & -.056 & .021 & $-.173^{* *}$ & -.098 & $.174^{* *}$ & $.574^{* *}$ & 1.000 & & \\
\hline Ownership 1 & .001 & $.174^{* *}$ & $-.145^{*}$ & -.031 & -.118 & .090 & .117 & 1.000 & \\
\hline Ownership 2 & .057 & $-.136^{*}$ & -.020 & -.047 & .099 & .029 & -.049 & $-.846^{* * *}$ & 1.000 \\
\hline Japanese CEO & .092 & -.040 & .118 & $.217^{* *}$ & -.029 & .008 & .012 & .101 & -.088 \\
\hline
\end{tabular}

** Significant at the 0.01 level (2-tailed).

* Significant at the 0.05 level (2-tailed).

Initial entry (Greenfield $=1$, Otherwise $=0$ )

Japanese emp (No. of Japanese employees)

Japanese emp exist (exist $=1$, otherwise $=0)$ )

Performance (low (loss \& break-even) $=0$, high=1)

Industry 1 (Manufacturing=1, Service $=0$ )

Industry 2 (Agriculture, forestry and fishing=1, Mining=2, Travel and Hotel=3, Manufacturing=4, Retail and Wholesale=5, Real Estate and Finance=6, Logistics and transport $=7$, other $=8$ )

Ownership 1 (Wholly-owned subsidiaries which own more than 95\% =1, Otherwise $=0$ )

Ownership $2($ WOS $(\mathrm{J})=1$, WOS $(\mathrm{DJ})=2, \mathrm{JV}(\mathrm{JJ})=3, \mathrm{JV}(\mathrm{JDJ})=4, \mathrm{JV}(\mathrm{JJL})=5, \mathrm{JV}(\mathrm{DJL})$ $=6, \mathrm{JV}(\mathrm{JDJL})=7), \mathrm{JV}(\mathrm{JL})=8$

Japanese CEO (exist $=1$, otherwise $=0$ )

Table 3 shows the means, standard deviations, and correlation coefficients for all the variables. Low coefficients suggest that the variables have little or no co-linearity. Higher correlations were observed between Japanese employees and existence of Japanese employees (labeled as Japanese emp exist), industry 1 and 2, and ownership 1 and 2. Therefore we refrained by using Japanese employees and ownership 2, and industry 2 in the regression analysis. 


\section{Macrothink}

Table 4: t-test results for Japanese Subsidiaries in Australia and New Zealand (N=275)

\begin{tabular}{|l|c|c|c|c|c|c|}
\hline & Mean & $\begin{array}{c}\text { Std. } \\
\text { Deviation }\end{array}$ & $\begin{array}{c}\text { Mean } \\
\text { difference }\end{array}$ & $\mathrm{F}$ & $\mathrm{df}$ & $\mathrm{t}$ \\
\hline Initial entry & .5782 & .49475 & .0028 & .004 & 38 & .029 \\
Age & 2.8693 & .53588 & .1193 & 4.713 & 48 & $1.168^{*}$ \\
Japanese emp exist & .7421 & .43837 & -.0002 & .000 & 39 & -.002 \\
Industry 1 & .2836 & .45158 & -.0652 & 2.857 & 39 & -.756 \\
Ownership 1 & .7418 & .43843 & -.0362 & .665 & 37 & -.433 \\
Japanese CEO & .8255 & .38027 & .0149 & .175 & 38 & .206 \\
Performance & .6364 & .48192 & -.2446 & 2.061 & 37 & $-2.692^{* *}$ \\
\hline
\end{tabular}

** Significant at 0.01 level, * Significant at 0.05 level

The $\mathrm{t}$-test results confirmed that only the age $(\mathrm{t}=1.168(48), \mathrm{p}<.05)$ and performance $(\mathrm{t}=2.692$ (37), $\mathrm{p}<.01$ ) were significantly different between Australia and New Zealand (Table 4). The mean differences between initial entry, existence of Japanese employees, industry 1, ownership 1, and Japanese CEO remained insignificant. These results indicated that the samples from the two countries were close enough to pool together to examine the predictors of the performance in Japanese subsidiaries.

The dependent variable of our research is a dichotomous variable with 0 representing low performance and 1 representing high performance. To evaluate the extent to which from entry mode, ownership, employees, and industry were associated with the performance we used binary logistic regression analysis. Except the control variable age, all other predictors were categorical variables. At first we tested the model for each country and then for the grouped data excluding the control variable. At the second stage we repeated the same including the control variable, age. The results are presented in Table 5. 
Table 5: Binary logistic regression models for performance of Japanese subsidiaries in Australia and New Zealand (excluding age)

\begin{tabular}{|l|c|c|c|}
\hline \multirow{1}{*}{ Variables } & Model 1 & Model 2 & Model 3 \\
\cline { 2 - 4 } & $\begin{array}{c}\text { Australia } \\
(\mathrm{N}=244)\end{array}$ & $\begin{array}{c}\text { New Zealand } \\
(\mathrm{N}=31)\end{array}$ & $\begin{array}{c}\text { Total } \\
(\mathrm{N}=275)\end{array}$ \\
\hline Age & $\mathrm{NI}$ & $\mathrm{NI}$ & $\mathrm{NI}$ \\
Initial entry & $-.371(1.440)$ & $-1.046(788)$ & $-.407(.2 .041)$ \\
Japanese emp exist & $.608(2.984)$ & $3.417(5.218)^{*}$ & $.798(6.016)^{*}$ \\
Industry 1 & $-1.209(13.723)^{* * *}$ & $-3.745(4.835)^{*}$ & $-1.256(16.452)^{* * *}$ \\
Ownership 1 & $-.730(3.721)$ & $-2.353(3.079)$ & $-.814(5.521)^{*}$ \\
Japanese CEO & $-.214(.231)$ & $-.634(.681)$ & $-.198(.239)$ \\
Constant & $1.640(8.870)^{* *}$ & $.532(.742)$ & $1.425(8.216)^{* *}$ \\
& & & \\
\hline Model Coefficients & & & $16.115 * *$ \\
Chi-square & $19.799 * *$ & .545 & $26.471 * * *$ \\
Nagelkerke R Sq & .120 & 26.05 & .137 \\
-2 log likelihood & 259.173 & 302.015 \\
\hline
\end{tabular}

*** Significant at 0.001 level, ** Significant at 0.01 level, * Significant at 0.05 level

Notes: Within brackets is Wald statistics.

Dependent variable is performance (low $=0$, high $=1$ ),

$\mathrm{NI}=$ not included

As shown in the Table 5, all the model coefficients were statistically significant (model 1: $\mathrm{p}<.01$, model 2: $\mathrm{p}<.01$, model 3: $\mathrm{p}<.001$, model 4: $\mathrm{p}, .001$, model 5: $\mathrm{p}, .05$, model 6:, .001 ). Without the influence of age, industry was a predictor for the performance in Australia, and for New Zealand the performance was significantly influenced by the existence of Japanese employees and industry. For the total sample we found Japanese employees, industry and the ownership as significant predictors. When the control variable age was inserted into the models as a predicting variable, there wasn't any change in the results in model 5 for New Zealand, but some changes appeared in model 4 and 6 for Australia and for the total sample respectively. Including age, industry and ownership appeared as significant for the model for Australia. Age, the existence of Japanese employees, industry and ownership were significant predictors for the total sample (Table 6). 
Table 6: Binary logistic regression models for performance of Japanese subsidiaries in Australia and New Zealand (including age)

\begin{tabular}{|l|c|c|c|}
\hline \multirow{1}{*}{ Variables } & $\begin{array}{c}\text { Model 4 } \\
\text { (age included) }\end{array}$ & $\begin{array}{c}\text { Model 5 } \\
\text { (age included) }\end{array}$ & $\begin{array}{c}\text { Model 6 } \\
\text { (age included) }\end{array}$ \\
\cline { 2 - 4 } & $\begin{array}{c}\text { Australia } \\
(\mathrm{N}=244)\end{array}$ & $\begin{array}{c}\text { New Zealand } \\
(\mathrm{N}=31)\end{array}$ & $\begin{array}{c}\text { Total } \\
(\mathrm{N}=275)\end{array}$ \\
\hline Age & $.637(4.416)^{*}$ & $.935(.512)$ & $.611(4.449)^{*}$ \\
Initial entry & $-.271(.737)$ & $-.670(.264)$ & $-.305(1.100$ \\
Japanese emp exist & $.523(2.154)$ & $3.386(4.705)^{*}$ & $.719(4.782)^{*}$ \\
Industry 1 & $-1.092(10.818)^{* *}$ & $-3.356(3.990)^{*}$ & $-1.135(12.973)^{* * *}$ \\
Ownership 1 & $-.918(5.399)^{*}$ & $-2.275(2.925)$ & $-.968(7.264)^{* *}$ \\
Japanese CEO & $-.188(.179)$ & $-.686(.189)$ & $-.167(.168)$ \\
Constant & $-.083(.007)$ & $-2.523(.308)$ & $-.274(.771)$ \\
& & & \\
\hline Model Coefficients & $24.329 * * *$ & $16.647 *$ & $31.049 * * *$ \\
Chi-square & .145 & .559 & .159 \\
Nagelkerke R Sq & 254.643 & 25.518 & 297.437 \\
-2 log likelihood & & & \\
\hline
\end{tabular}

*** Significant at 0.001 level, ** Significant at 0.01 level, * Significant at 0.05 level

Notes: Within brackets is Wald statistics.

Dependent variable is performance (low $=0$, high $=1$ ),

$\mathrm{NI}=$ not included

Going one step further we tested three more models with age and country interactions for the total sample (see table 7). Since we found significant differences in age and performance between the two countries we assumed that there would be some different results by introducing the interactions of age and country. The model coefficients for the all three models became significant (Model 7: p<.001, model 8: $\mathrm{p}<.001$, model 9: $\mathrm{p}<.001$ ). Age and industry interaction appeared as significant in the model 7. For the model 9 we inserted only the interaction variables. The interactions of Japanese employees, industry, and country with age showed as significant predictors. Country and Japanese employees also became significant. 
Table 7: Binary logistic regression models for performance of Japanese subsidiaries in Australia and New Zealand with country and age interactions

\begin{tabular}{|c|c|c|c|}
\hline \multirow[t]{2}{*}{ Variables } & $\begin{array}{c}\text { Model } 7 \\
\text { (age interactions) }\end{array}$ & $\begin{array}{c}\text { Model } 8 \\
\text { (country } \\
\text { interactions) }\end{array}$ & $\begin{array}{c}\text { Model } 9 \\
\text { (country and age } \\
\text { interactions) }\end{array}$ \\
\hline & $(\mathrm{N}=275)$ & $(\mathrm{N}=275)$ & $(\mathrm{N}=275)$ \\
\hline Initial entry & $-2.177(1.316)$ & $-2.395(1.157)$ & NI \\
\hline Japanese emp exist & $-.553(.083)$ & $5.920(4.072)^{*}$ & NI \\
\hline Industry 1 & $2.912(2.036)$ & $-7.280(4.606)^{*}$ & NI \\
\hline Ownership 1 & $.182(.009)$ & $-4.820(3.708)^{*}$ & NI \\
\hline Japanese CEO & $-2.307(1.198)$ & $-1.633(.293)$ & $\mathrm{NI}$ \\
\hline Age $x$ entry & $.650(1.005)$ & NI & $.034(.008)$ \\
\hline Age $x$ Japanese emp exist & $.459(.475)$ & NI & $.906(4.003) *$ \\
\hline Age $\mathrm{x}$ industry 1 & $-1.439(4.004)^{*}$ & NI & $-1.784(8.456)^{* *}$ \\
\hline Age $x$ ownership 1 & $-.331(.244)$ & NI & $-.791(3.121)$ \\
\hline Age x Japanese CEO & $.616(.761)$ & NI & $-.026(.003)$ \\
\hline Age $x$ country & NI & NI & $.601(17.970)^{* * *}$ \\
\hline Country $\mathrm{x}$ entry & NI & $1.020(.801)$ & $-.934(1.987)$ \\
\hline Country x Japanese emp exist & $\mathrm{NI}$ & $-2.648(3.129)$ & $1.948(4.984)^{*}$ \\
\hline Country $\mathrm{x}$ industry 1 & $\mathrm{NI}$ & $3.045(3.162)$ & $.644(.992)$ \\
\hline Country x ownership1 & NI & $2.066(2.629)$ & $-.297(.166)$ \\
\hline Country x Japanese CEO & $\mathrm{NI}$ & $.736(.227)$ & $-.196(.115)$ \\
\hline Constant & $1.620(8.806)^{* *}$ & $1.525(8.763)^{* *}$ & $-1.358(3.820)^{*}$ \\
\hline Model Coefficients & & & \\
\hline Chi-square & $35.165 * * *$ & $42.835 * * *$ & $50.401 * * *$ \\
\hline Nagelkerke R Sq & .179 & .215 & .249 \\
\hline-2 log likelihood & 293.321 & 285.650 & 278.085 \\
\hline
\end{tabular}

*** Significant at 0.001 level, ** Significant at 0.01 level, * Significant at 0.05 level

Notes: Within brackets is Wald statistics.

Dependent variable is performance (low $=0$, high $=1$ ),

$\mathrm{NI}=$ not included

Part (a) of the hypothesis 1 on Greenfield entry was not supported. It did not appear as a significant predictor in any of the models. The reason might be the longer years of experience in the host country. In part (b) of hypothesis 1 we assumed that wholly-owned subsidiaries would perform better than joint ventures. This was not supported for New Zealand where the majority of the subsidiaries were wholly-owned but only $42 \%$ of the subsidiaries had high performance and the ownership variable in the model was insignificant. Sole ownership was a 
significant predictor for performance in the total sample and in Australia where $66 \%$ of the subsidiaries were high performers but the sign was negative.

The other interesting revelation was to find that only 4 Japanese subsidiaries in our New Zealand sample had local partners and the rest of the subsidiaries which consisted of 27 firms were owned by Japanese companies only. Twenty three subsidiaries were wholly-owned subsidiaries, and 4 subsidiaries were owned by Japanese-Japanese firms. Among Japanese subsidiaries in Australia 162 firms were recorded as high performers. Two hundred and four Australian subsidiaries were wholly-owned and only 71 were joint ventures. Within those 71 firms, only 28 joint ventures had foreign partners. This finding for the Australian sample confirmed the findings by Woodcock et al. (1994), Siripaisalpipat and Hoshino (2000) and Cieslik and Ryan (2009).

Hypothesis 2 on industry was supported. The influence of industry was significant in both countries. Even though the close proximity of Australia and New Zealand means they share some similar demographic characteristics, it seems that the two countries have some different aspects therefore Japanese MNCs approached the two countries with different strategies. The control variable age was significant with Australian data and with the total sample, but not significant with New Zealand data, but appeared its influence in the increased chi square values and likelihood ratios (see table 5 and 6). The majority of JFDI in New Zealand focused on the trade and travel sectors and they have reported both high and low performance. There were 24 subsidiaries in the service sector and 12 of them were high performers and 12 were low performers. In the manufacturing sector there were 7 subsidiaries, 6 of which were low performers. Subsidiaries in travel and retail markets were able to enjoy high profits. In Australia retail $(41 \%)$ was the leading sector followed by the real estate sector $(17 \%)$. Agriculture (13.6\%), manufacturing (11.7\%) and travel (9\%) were lined up next. $72 \%$ of the service sector firms were high performers. In the manufacturing sector, the proportion of high performance was $52 \%$.

With the economic deregulation of the mid 1980s New Zealand became a more open economy compared with other international capital markets, but due to strict environmental policies, New Zealand is still a restricted economy for the manufacturing sector. That led Japan, as a foreign manufacturer, to select their investments very carefully ending up with less manufacturing plants in New Zealand which has been a positive contribution for New Zealand's clean green environment efforts. According to Everett (1996), foreign investment funds have found banking and finance, manufacturing, and property as the most attractive sectors in New Zealand. Trade has been identified as a sector dominated by foreign majority-owned firms. The relationship we found here between Japanese subsidiaries and trade sector confirms Everett's findings. They have seemed as heavily involved in trade and travel which are not labour intensive or high-tech industries. Ranft and Marsh (2008) depict that performance is higher when firms enter low knowledge-intensive environments or high knowledge intensive environment regardless of the mode of entry. In the markets with lower knowledge-based resources, performance would be higher because the market is less 
problematic, and when intensity increases performance declines to a point. However, in high-knowledge intensive environments there is a positive relationship between knowledge intensity and performance (Ranft and Marsh, 2008).

Hypothesis 3 on Japanese employees was partially supported. Having a Japanese CEO was not an influencing factor for better performance, but existence of Japanese employees showed a positive and significant influence in New Zealand than in Australia but it doesn't seem to be a positive factor for better performance because the majority of the firms were low performers. $92 \%$ of the subsidiaries in New Zealand had Japanese employees while it was around 77\% in Australia. As Konopaske et al (2002) found out in their research the results in this study also indicated that the staffing approach has a significant impact on performance. There may be some other aspects behind those staffing policies and that is beyond the scope of this study.

This study extends our understanding of the influence of ownership and staffing policies on Japanese subsidiary performance in Australia and New Zealand. Greenfield initial entry and Japanese CEO had not been proven as influencing factors for better performance in the recent years. Since the average age of the subsidiaries in both countries is nearly 20 years therefore, the influence of entry mode and CEO may have disappeared. Industry, ownership, Japanese employees, and subsidiary age were seen as predictors of performance in Australia and New Zealand the impacts were both positive and negative.

\section{Conclusion}

In this study we investigated the influence of entry mode, ownership structure, industry, staffing policy on subsidiary performance in Australia and New Zealand. To test our model we used logistic regression. Our hypotheses were partially supported indicating significant influence of related industry, existence of Japanese employees, and ownership on the performance of Australian and New Zealand subsidiaries. The moderating factor, age, became significant with Japanese employees, ownership and industry as predictors of performance. This research was not free from limitations. The results were drawn on a sample of subsidiaries in Australia and New Zealand. Therefore the findings are country and region specific. This is a part of on-going research. The analysis was limited to the companies with performance measure and it was subjective. In order to derive strong conclusions, more quantifiable measures need to be added to the performance variables and also the sample size for New Zealand need to be increased. These issues will be addressed in another paper.

In this paper we also did not address the issue of the direct investments in New Zealand by Australian companies which affiliate with Japanese investors. Subsidiaries rely on multiple sources for competitive advantage and parent companies play an important role in providing resources associated with these competitive advantages. The empirical evidence shows that the majority of the subsidiaries are the dominant, or the only firm of that industry, in New Zealand. They have collaborative linkages with the parent companies, involving two-way transfer of resources including unique product or service related technologies. Local firms 
also improve their capabilities through the links with the subsidiaries. Therefore, local industry movements and strategic location need to be addressed in a separate paper.

\section{Acknowledgement}

An earlier version of this paper was presented at the Performance Measurement Association Conference in Dunedin, New Zealand in April 2009. We thank session participants and also the anonymous reviewers of the Asian Journal of Finance and Accounting for their helpful comments and suggestions. All errors and omissions are the responsibility of the authors.

\section{References}

Alba, J. D., Park, D., \& Wang, P. (2008). Corporate Governance and Merger \& Acquisition (M\&A) FDI: Firm-level Evidence from Japanese FDI into the US, Journal of Multinational Financial Management, 1,1-11.

Anand, J. \& Delios, A. (1997). Location Specificity and the Transferability of Downstream Assets to Foreign Subsidiaries, Journal of International Business Studies, 28 (3), 579-603.

Bamber, G. J., Shadur, M. A.,, \& Howell, F. (1992). The International Transferability of Japanese Management Strategies: an Australian Perspective, Employee Relations, 14(3), 3-20.

Beamish, P. W. \& Inkpen, A. (1998). Japanese firms and the decline of the Japanese Expatriate. Journal of World Business, 33 (1), 35-50.

Beamish, P. W. \& Ruihua, J. (2002). Investing Profitably in China: Is it Getter Harder? Long Range Planning, 35 (2). 135-151.

Beamish P. W. \& Jae, J. (2005). The Performance and Survival of Joint Ventures with Parents of Asymmetric Size, International Management, 10 (1), 19-30.

Ben_Youssef, K. \& Hoshino, Y. (2007). The Influence of Firm-specific Advantages and Entry Mode Choice on Performance: the Case of Japanese Foreign Direct Investment in Australia, International Journal of Service Technology \& Management, 8 (4/5), 329-343.

Cieslik, A. \& Ryan, M. (2009). Firm Heterogeneity, Foreign market Entry Mode and Ownership Choice, Japan and the World Economy, 21 (3), 213-218.

Delios, A. \& Ensign, P. C. (2000). A Sub national Analysis of Japanese Direct Investment in Canada, Canadian Journal of Administrative Sciences, 17(1), 38-51.

De Silva, L. S. (2006). Direct Investment and Japanese Subsidiaries in Australia, The Otemon 
Journal of Australian Studies, 32, 93-110.

Everett, A. M. (1996). Strategic Management of International Business Relationships with New Zealand, Management Decision, 34 (9), 82-104.

Gorg, H. (2000). Analyzing Foreign Market Entry: The Choice between Greenfield Investment and Acquisitions, Journal of Economic Studies, 27 (3), 165-181.

Harzing, A. W. (2002). Acquisitions versus Greenfield Investments: International Strategy and Management of Entry Modes, Strategic Management Journal, 23 (3), 211-227.

Ito, K. \& Rose, E. L.(1994). Subsidiary Ownership Policies of Japanese Manufacturing Firms, Academy of Management Meetings, Dallas, August 15.

Johnston, S. \& Menguc, B. (2007). Subsidiary Size and the Level of Subsidiary Autonomy in Multinational Corporations: A Quadratic Model Investigation of Australian Subsidiaries, Journal of International Business Studies, 38 (5), 787-801.

Kasuga, H. (2008). Exchange rates and Ownership Structure of Japanese Multinational Firms, Japan and the World Economy, 20, 661-678.

Konopaske, R. Werner, S. \& Neupert, K. E. (2002). Entry Mode Strategy and Performance; the Role of FDI Staffing, Journal of Business Research, 55 (9), 759-770.

Makino, S. \& Kent, E. N., (2000). National Culture, Transaction Costs, and the Choice between Joint Venture and Wholly-Owned Subsidiary, Journal of International Business Studies,_31 (4). 705-713.

Mansour, M. \& Hoshino, Y. (2002). Entry Mode Choice of the Japanese MNEs in Europe: Impact of Firm and Industrial Factors, Japanese Journal of Administrative Science, 15(3), 231-247.

Nitsch, D., Beamish, P. \& Makino, S. (1996). Entry Mode and Performance of Japanese FDI in Western Europe, Management International Review, 36 (1), 27-43.

Ogasavara, M. H. \& Hoshino, Y. (2009). Implications of firm experiential knowledge and sequential FDI on performance of Japanese subsidiaries in Brazil, Review of Quantitative Finance and Accounting, 33 (1), 37-58.

Ogasavara, M. H. \& Hoshino, Y. (2007). The Impact of Ownership, Internationalization, and Entry Mode on Japanese Subsidiaries' Performance in Brazil, Japan and the World Economy, $19(1), 1-25$.

Okamoto, Y. (1998). Direction and Problems of Basic Strategies of Japanese Multinationals 


\section{Macrothink}

in East Asia, In Y. Takahashi, M. Murata \& K. Rahman (Eds.), Management Strategies of Multinational Corporations in Asian Markets, P. 21, Chuo University Press, Tokyo.

Ranft, A. L. and Marsh, S. J. (2008). Assessing Knowledge through Acquisitions and Alliances; An Empirical Examination of New Market Entry, Journal of Management Issues, 20 (1), 51-67.

Rasouli G., M. \& Hoshino, Y. (2007). Establishment, Survival, Sales Growth and Entry Strategies of Japanese MNCS Subsidiaries in India, Journal of Developmental Entrepreneurship, 12(4), 433-447.

Scott-Kennel, J. (2004). Foreign Direct Investment to New Zealand, University of Auckland Business Review, 6 (2), 41-49.

Siripaisalpipat, P. \& Hoshino, Y. (2000). Firm-specific Advantages, Entry Modes, and Performance of Japanese FDI in Thailand, Japan and the World Economy, 12 (1), 33-48.

Statistics New Zealand, New Zealand Economic \& Financial Overview, 2008.

Woodcock, C. P., Beamish, P.W. \& Makino, S., (1994). Ownership-based entry mode strategies and international performance, Journal of International Business Studies, 25 (2), 253-273.

Yeh, T. \& Hoshino, Y. (2000). The Effects of Mergers and Acquisitions on Taiwanese Corporations, Review of Pacific Basin Financial Markets and Policies, 3(2), 183-199. 